\title{
SIMULASI PENGOLAHAN LIMBAH CAIR BERWARNA DENGAN FOTO FENTON PADA SISTEM KONTINYU
}

\author{
Lie Hwa*, Lieke Riadi \\ Jurusan Teknik Kimia, Fakultas Teknik \\ Universitas Surabaya \\ Jalan Raya Kalirungkut, Surabaya 60292 \\ Email: liehwa@ubaya.ac.id
}

\begin{abstract}
Abstrak
Pengolahan limbah cair industri pengolahan kopi dilakukan dengan metode Foto Fenton. Kajian menggunakan limbah sintetis berwarna coklat, mengandung kopi 300 ppm. Percobaan dilakukan dalam sebuah reaktor gelas dua liter yang dilengkapi dengan lampu ultra violet. Reagen yang digunakan adalah hidrogen peroksida dengan konsentrasi $700 \mathrm{ppm}$ yang dibuat dari $\mathrm{H}_{2} \mathrm{O}_{2} 30 \%$, dan besi sulfat $15 \mathrm{ppm}$. Pengolahan limbah dilakukan pada $\mathrm{pH}=3$. Dengan penambahan reagen fenton dan bantuan lampu ultra violet, warna limbah cair berubah secara perlahan dari coklat menjadi kuning dan akhirnya tidak berwarna. Perubahan absorbansi relatif zat warna, kandungan bahan organik total diukur terhadap waktu. Berdasarkan data percobaan secara batch, kinetika degradasi karbon mengikuti orde satu terhadap konsentrasi bahan organik total. Aplikasi untuk sistem kontinyu dibuat menggunakan model simulasi penurunan kandungan organik dalam sebuah reaktor berpengaduk dan 4 buah reaktor berpengaduk yang dihubungkan secara seri. Dengan laju alir umpan tetap, peningkatan volume reaktor akan memperbesar waktu tinggal reaktan dalam reaktor. Hasil simulasi reaktor tunggal menunjukkan bahwa semakin lama waktu tinggal maka semakin tinggi persentase penurunan bahan organik total. Untuk mendegradasi $90 \%$ kandungan organik dalam limbah, sebuah reaktor kontinyu seharusnya dirancang dengan waktu tinggal 1100 menit sedangkan empat buah reaktor dirancang dengan waktu tinggal 100 menit.
\end{abstract}

Kata kunci: foto fenton, limbah cair berwarna, kontinyu,waktu tinggal

\begin{abstract}
Wastewater from coffee processing was treated by the Photo Fenton method. Experiments were carried out in a 2 liter batch reactor equipped with ultraviolet lamp for 4 hours. The synthetic waste water was made by dissolving $300 \mathrm{mg}$ instant coffee in 1 liter water. Reagents used are $700 \mathrm{ppm} \mathrm{H}_{2} \mathrm{O}_{2}$ prepared from $30 \% \mathrm{H}_{2} \mathrm{O}_{2}$, and 15 ppm FeSO $\mathrm{F}_{4} .7 \mathrm{H}_{2} \mathrm{O}$. The experiment was carried out at $\mathrm{pH}=3$. Prior to treatment, the color of the wastewater was brownish yellow. After adding the fenton reagent under UV light exposure, the color of wastewater changed to pale yellow, and finally became colorless. Absorbance and Total Organic Carbon (TOC) of the sample were measured periodically. The kinetics of organic carbon degradation followed first order reaction towards the TOC concentration. Based batch experiment data, organic degradation was simulated for a single CSTR and four CSTRs in series. The single CSTR with a residence time of 1100 minutes can reduce the organic content from $108 \mathrm{ppm}$ to $10.8 \mathrm{ppm}$, whereas for the serial CSTR reactors, the residence time was only 100 minutes in each reactor to get the same percentage reduction.
\end{abstract}

Keywords: photo fenton, colored waste water, continuous, residence time

*korespondensi 


\section{Pendahuluan}

Kopi merupakan komoditi komersial yang banyak diminati banyak negara. Namun dampak lingkungan dari pemrosesan kopi kurang banyak diketahui baik oleh produsen maupun konsumen kopi. Chanakya dan Alwis (2004) menjelaskan dampak lingkungan dari proses pengolahan kopi serta menyarankan suatu cara untuk meminimalkan limbah dan air dalam industri kopi di India. Di Zimma Zone (Ethiopia), Haddis dan Devi (2008) mengamati bahwa kandungan BOD dan COD sungai yang menerima buangan dari industri kopi meningkat dari masing-masing sekitar 120 dan $176 \mathrm{mg} / \mathrm{L}$ menjadi 7800 dan $9780 \mathrm{mg} / \mathrm{L}$. Berbagai penelitian untuk mereduksi warna dan kandungan bahan organik dalam limbah kopi telah dilakukan.

Limbah cair dari industri kopi yang berwarna kecoklatan banyak mengandung bahan-bahan organik seperti pektin, protein dan gula. Komponen utama dalam limbah ini adalah melanoidin. Menurut Chandra dkk. (2008) senyawa ini memiliki gugus amino karbonil dengan berat molekul yang besar, yang dihasilkan dari reaksi pencoklatan nonenzimatik Maillard. Struktur melanoidin yang kompleks mengakibatkan limbah cair ini sulit didegradasi secara biologis. Seperti umumnya sifat zat warna yang dibuang ke perairan bebas, komponen ini juga akan menghalangi masuknya sinar matahari ke dalam perairan, sehingga proses fotosintesis di perairan tersebut akan terganggu (Teixeira dkk., 2005).

Proses penghilangan warna dari limbah kopi ini, dilakukan dengan metode Foto-Fenton yang telah dilakukan secara batch oleh Tokumura dkk. (2006). Reaksi ini akan mempercepat hilangnya zat warna dalam limbah akibat hilangnya gugus aromatik dalam proses depolimerisasi melanoidin. Model limbah kopi sintetik dibuat di laboratorium dengan melarutkan kopi instant Nescafe Goldblend (Nestle Japan Group). Limbah ditambahi asam sulfat agar memiliki $\mathrm{pH}=3$. Percobaan dilakukan dalam reaktor gelas bervolume 1 liter yang dilengkapi dengan 4 buah lampu ultraviolet $15 \mathrm{~W}$ (black light) dengan panjang gelombang $352 \mathrm{~nm}$. Reagen hidrogen peroksida dan besi sulfat ditambahkan pada awal proses dengan perbandingan tertentu. Perubahan absorbansi, kandungan organik total serta konsentrasi ion besi (II) diukur selama reaksi berlangsung. Dengan metoda ini, kandungan polutan organik dalam limbah cair dapat direduksi selama 240 menit untuk konsentrasi kopi awal 300 mg/L.
Hal ini nampak dari perubahan warna limbah dari coklat menjadi kuning hingga jernih. Data kinetika kecepatan reduksi warnanya dinyatakan dalam hubungan absorbansi warna relatif terhadap waktu dan dibagi menjadi tiga fasa. Fasa pertama adalah fasa dimana terjadi peningkatan absorbansi pada awal penambahan reagen Fenton. Pada fasa kedua terjadi penurunan absorbansi warna yang merupakan reaksi orde dua, dikuti fasa ketiga yang merupakan reaksi orde pertama. Konstanta kecepatan reaksinya dipengaruhi oleh kekuatan lumen. Semakin besar intensitas cahaya yang digunakan, semakin besar pula konstanta kecepatan reaksinya.

Dalam penelitian berikutnya, proses penghilangan warna limbah kopi dengan metode Foto Fenton dilakukan dengan menggunakan sinar matahari menggantikan lampu ultra violet. Tokumura dkk. (2006) meneliti pengaruh cuaca (hari terik, mendung, malam hari) terhadap kecepatan penghilangan warna limbah kopi. Secara umum, udara terik akan mempercepat laju degradasi warna limbah kopi, sedangkan pada malam hari laju degradasinya paling rendah dibandingkan saat cuaca mendung dan cuaca cerah. Kandungan organik total dapat direduksi dari $109 \mathrm{mg} / \mathrm{L}$ menjadi $20 \mathrm{mg} / \mathrm{L}$.

Penelitian dalam makalah ini dilakukan dalam dua tahap, yaitu percobaan dalam sebuah reaktor batch dan simulasi rangkaian reaktor kontinyu berdasarkan data kinetika yang diperoleh dari percobaan reaktor batch. Model reaktor yang digunakan adalah reaktor alir berpengaduk kontinyu (continuous stirred-tank reactor) menurut Fogler (1999) yang dilengkapi dengan lampu ultraviolet dan disebut reaktor foto fenton kontinyu berpengaduk. Pengaruh laju alir umpan terhadap kinerja reaktor dinyatakan sebagai waktu tinggal umpan dalam reaktor terhadap persentase penurunan kandungan zat organik dalam limbah. Waktu tinggal umpan ini merupakan perbandingan antara volume reaktor terhadap laju alir volumetrik umpan.

Penghilangan warna gelap dari limbah kopi dapat dilakukan dengan beberapa proses, yaitu fenton, foto-fenton, fotolisis, dan fotokatalis. Pada metoda fenton, limbah kopi diolah menggunakan $\mathrm{Fe}^{2+}$ dan hidrogen peroksida, sehingga terbentuk radikal hidroksil. Radikal hidroksil ini menyerang polutan organik dalam limbah. Proses foto-fenton merupakan pengembangan dari proses fenton dengan menambahkan lampu ultraviolet untuk mempercepat dan memperbanyak radikal 
hidroksil yang terbentuk (Tokumura dkk., 2006). Proses fotolisis dilakukan dengan menggunakan hidrogen peroksida dan sinar UV agar terbentuk radikal hidroksil, namun tanpa menggunakan besi sulfat.

Radikal hidroksil yang terbentuk pada reaksi fenton berasal dari reaksi besi (II) dengan hidrogen peroksida:

$\mathrm{Fe}^{2+}+\mathrm{H}_{2} \mathrm{O}_{2} \rightarrow \mathrm{Fe}^{3+}+\cdot \mathrm{OH}+\mathrm{OH}^{-}$

Proses foto-fenton menggunakan ion $\mathrm{Fe}(\mathrm{II})$ dan $\mathrm{H}_{2} \mathrm{O}_{2}$, serta sinar UV untuk pembentukan $\cdot \mathrm{OH}$. Reaksi yang terjadi seperti reaksi (1) pada proses fenton, disertai dengan reaksi (2) dan (3) di bawah ini:

$\mathrm{H}_{2} \mathrm{O}_{2}+\mathrm{hv} \rightarrow \cdot \mathrm{OH}+\cdot \mathrm{OH}$ (fotolisis dari hidrogen peroksida)

$\mathrm{Fe}^{3+}+\mathrm{H}_{2} \mathrm{O}+\mathrm{hv} \rightarrow \mathrm{Fe}^{2+}+\cdot \mathrm{OH}+\mathrm{H}^{+}$(reaksi fotofenton)

Karena model limbah kopi ini mengandung banyak makromolekul yang tidak teridentifikasi termasuk melanoidin, reaksi penghilangan warna mungkin sedikit rumit. Tokumura dkk. (2006) menyatakan bahwa proses penghilangan warna pada limbah kopi dapat dibagi dalam tiga fasa. Perubahan warna dalam limbah cair diamati dengan melakukan pengukuran perubahan absorbansi relatif terhadap waktu. Ketika larutan ditambah dengan $\mathrm{H}_{2} \mathrm{O}_{2}$, warna dari larutan berubah secara cepat, dan absorbansinya meningkat secara drastis. Peristiwa ini menunjukkan terjadinya fasa I, yang diikuti dengan penghilangan warna secara signifikan dan cepat pada fasa II. Setelah beberapa waktu, limbah menjadi jernih dan ditunjukkan dengan absorbansi larutan yang cenderung konstan. Peristiwa ini menunjukkan terjadinya fasa III. Menurut Tokumura dkk. (2006), penentuan ketiga fasa ini dilakukan berdasarkan data perubahan absorbansi relatif dan data perubahan konsentrasi ion besi (II) dan besi (III) terhadap waktu.

Sukharaharja dkk (2010) telah mempelajari proses penghilangan warna pada limbah kopi ini secara batch. Perubahan absorbansi, konsentrasi ion-ion besi (II dan III) dan kandungan bahan organik diukur terhadap waktu. Data perubahan absorbansi relatif terhadap waktu memiliki kecenderungan yang sama dengan data yang diperoleh Tokumura dkk (2006).
Pada sistem kontinyu, limbah kopi mengalir masuk dan keluar secara kontinyu dengan laju alir tertentu. Reaktor tangki berpengaduk dilengkapi dengan lampu sinar ultra violet seperti yang digunakan dalam percobaan secara batch. Menurut Zhang dkk. (2006) yang mempelajari pengolahan limbah cair dalam sebuah reaktor berpengaduk kontinyu dengan metode fenton, menyatakan kinetika reaksi degradasi bahan organik merupakan reaksi orde dua dengan persamaan sebagai berikut:

$-\mathrm{r}=\mathrm{k} \cdot \mathrm{C} \cdot \mathrm{OH} \cdot \mathrm{C}$

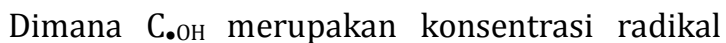
hidroksil dan $\mathrm{C}$ konsentrasi bahan organik dalam limbah cair yang dapat dinyatakan dalam COD ataupun TOC, $\mathrm{k}$ adalah konstanta kecepatan reaksi orde dua. Jika konsentrasi radikal hidroksil sangat tinggi, kinetika reaksinya dapat menjadi kinetika reaksi orde satu semu, yang laju reaksinya hanya merupakan fungsi dari konsentrasi kandungan organik total:

$-r=k_{\exp } . C$

Dengan $\mathrm{k}_{\text {exp }}$ adalah perkalian antara konstanta kecepatan reaksi orde dua, $\mathrm{k}$, dengan konsentrasi radikal hidroksil, $\mathrm{C}$.OH.

\section{Metodologi}

Penelitian dilakukan dalam bejana berpengaduk dengan volume limbah $1 \mathrm{~L}$. Limbah kopi sintetik dibuat dari kopi instan Nescafe dengan konsentrasi kopi 300 dan 400 mg per liter larutan. Kondisi $\mathrm{pH}$ awal ditetapkan 3 yang merupakan $\mathrm{pH}$ optimum menurut penelitian Tokumura dkk (2008). Reagen yang digunakan adalah hidrogen peroksida 30\% dan ion besi (II) diperoleh dari $\mathrm{FeSO}_{4} \cdot 7 \mathrm{H}_{2} \mathrm{O}$. Lampu sinar ultraviolet yang digunakan memiliki intensitas cahaya 9,01 W/m. Sampel diambil tiap 30 menit. Perubahan absorbansi relatif dan konsentrasi ion besi dan kandungan organik total dicatat terhadap waktu. Pengukuran absorbansi menggunakan spektrofotometer Hach DR/2000 pada panjang gelombang 400 $\mathrm{nm}$. Sedangkan untuk analisis ion besi (II) dan besi total digunakan 1,1-phenantroline dengan spektrofotometer UV-Vis. Analisis kandungan organik total diukur dengan TOC analyzer V-CN.

Sistem yang dipelajari untuk proses kontinyu adalah sebuah fotoreaktor kontinyu yang serupa dengan reaktor berpengaduk ideal kontinyu (CSTR), berupa rangkaian 4 buah reaktor berpengaduk yang dihubungkan secara 
seri. Konsentrasi umpan bahan organik dalam aliran inlet sama dengan data pada reaktor batch, yaitu kopi dengan kosentrasi awal 300 mg kopi/liter larutan. Waktu tinggal reaktor tunggal divariasikan untuk mengetahui persentase degradasi bahan organik.

Untuk percobaan dalam reaktor batch, hubungan konsentrasi bahan organik total (C) terhadap waktu $(\mathrm{t})$ mengikuti persamaan:

$\mathrm{C}=\mathrm{C}_{0} \cdot \mathrm{e}^{-\mathrm{kexp} \cdot \mathrm{t}}$

Dengan $\mathrm{C}_{\mathrm{o}}$ adalah konsentrasi bahan organik total dalam umpan. Gambar 1 menunjukkan skema fotoreaktor serta foto alat yang sesungguhnya yang digunakan dalam percobaan yang dilakukan secara batch.

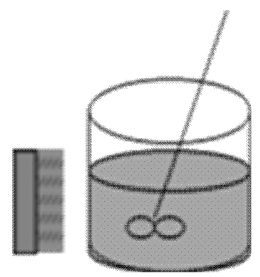

(a)

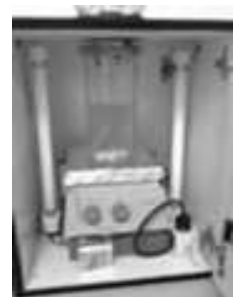

(b)

Gambar 1. (a) Skema foto reaktor yang beroperasi secara batch (b) Gambar foto reaktor yang digunakan di laboratorium

Untuk mempelajari pengaruh waktu tinggal umpan terhadap kinerja fotoreaktor kontinyu digunakan 2 model reaktor, yaitu reaktor tunggal dan empat buah reaktor yang dihubungkan seri (Fogler, 1999). Skema model reaktor kontinyu tersebut ditunjukkan dalam Gambar 2.

\subsection{Fotoreaktor Tunggal}

Untuk mempelajari dinamika konsentrasi bahan organik total dalam fotoreaktor kontinyu sebelum mencapai keadaan tunak, dibuat persamaan neraca bahan organik total dalam sebuah reaktor kontinyu:

$$
Q\left(C_{0}-C\right)+V \cdot r=V \frac{d C}{d t}
$$
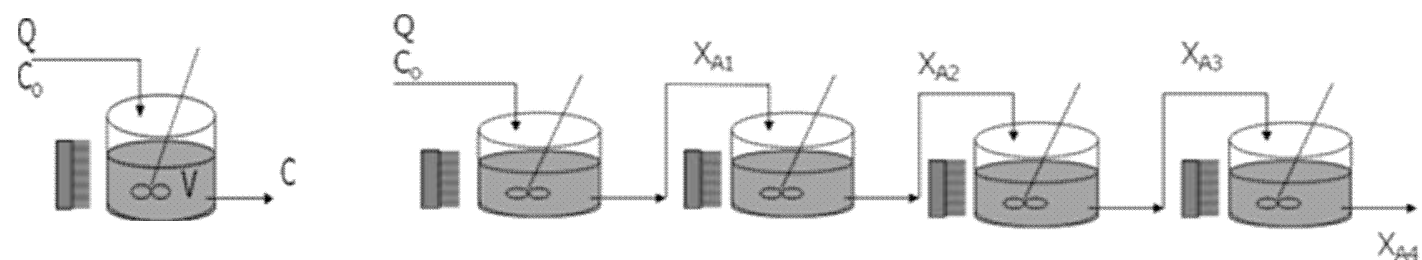

Gambar 2. Skema model foto reaktor kontinyu (a) tunggal dan (b) 4 reaktor dihubungkan seri untuk simulasi pengolahan limbah cair dengan metode foto fenton 
dari coklat menjadi kuning dan akhirnya jernih. Reaksi ini berlangsung selama 240 menit.

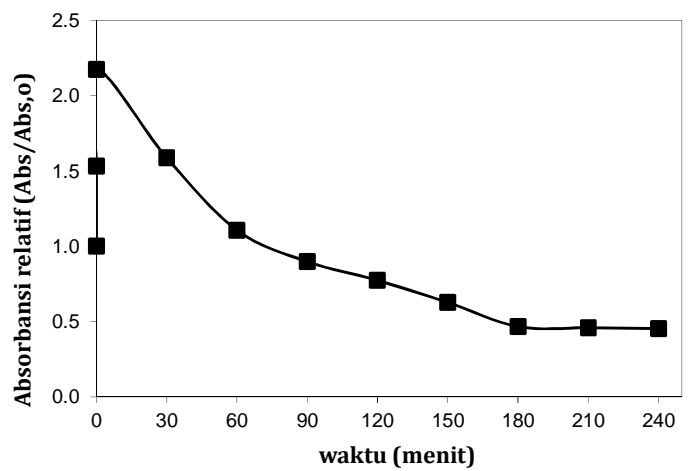

Gambar 3. Hubungan absorbansi relatif limbah kopi terhadap waktu dengan konsentrasi kopi awal $=\mathbf{4 0 0} \mathrm{ppm}$ dalam fotoreaktor batch

Zhang dkk. (2006) menjelaskan bahwa kinetika degradasi bahan organik dalam limbah cair sangat kompleks, namun dapat didekati dengan reaksi orde dua dan dituliskan dalam Persamaan 4. Jika radikal hidroksil yang terbentuk sangat banyak, persamaan kinetika degradasinya menjadi persamaan orde satu semu terhadap kandungan organik total dalam limbah (TOC) seperti tertulis pada Persamaan 5. Perubahan konsentrasi bahan organik dalam limbah terhadap waktu mengikuti pola kinetika reaksi orde satu seperti yang ditunjukkan pada Gambar 4.

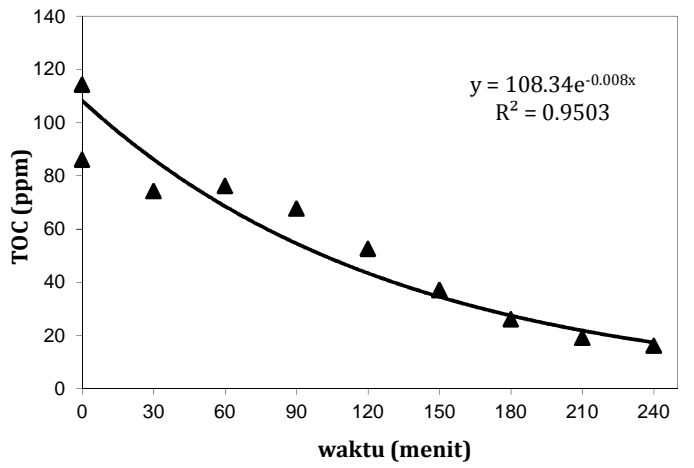

Gambar 4. Perubahan kandungan organik terhadap waktu (Co=300 ppm) dalam fotoreaktor batch mengikuti kinetika reaksi orde satu semu

Gambar 4 menampilkan hasil percobaan yang menggunakan konsentrasi kopi awal 300 ppm dengan kandungan bahan organik total (TOC) 114 ppm. Penyelesaian regresi dari persamaan reaksi orde satu (Persamaan 5) -
$\mathrm{dC} / \mathrm{dt}=\mathrm{k}_{\exp } \cdot \mathrm{C}$, adalah $\mathrm{C}=\mathrm{C}_{0} \cdot \mathrm{e}^{-\mathrm{kexp} \cdot \mathrm{t}}$. Data percobaan yang diperoleh menunjukkan bahwa persamaan ini menggambarkan perilaku konsentrasi bahan organik dalam reaktor batch terhadap waktu dengan persamaan $\mathrm{C}=$ 108,34.exp-0,0076.t. Harga koefisien korelasi hasil regresi adalah sebesar $95 \%$, dengan nilai $\mathrm{k}_{\exp }$ adalah 0,0076 menit ${ }^{-1}$. Model persamaan di atas sesuai dengan yang dikemukakan oleh Zhang dkk. (2006).

\subsection{Reaktor Berpengaduk Kontinyu (CSTR)}

Dari data kinetika secara batch, dirancang fotoreaktor kontinyu untuk kondisi umpan yang sama dengan reaktor batch. Ada 3 hal yang akan dibahas dari hasil penelitian ini, meliputi:

- Dinamika konsentrasi bahan organik sebelum mencapai keadaan tunak dalam fotoreaktor tunggal kontinyu

- Pengaruh waktu tinggal umpan dalam fotoreaktor kontinyu tunggal pada kondisi tunak

- Pengaruh waktu tinggal umpan dalam empat buah fotoreaktor kontinyu yang dihubungkan seri pada kondisi tunak

\subsection{Fotoreaktor Tunggal Sebelum Mencapai Kondisi Tunak}

Untuk mempelajari dinamika konsentrasi bahan organik sebelum mencapai keadaan tunak, fotoreaktor tunggal dirancang untuk menurunkan $75 \%$ kandungan bahan organiknya yang hasilnya menunjukkan waktu tinggal yang dibutuhkan dalam reaktor sebesar 400 menit. Dengan berjalannya waktu, persentase degradasi bahan organik dalam reaktor terus meningkat sampai konversi $75 \%$ tercapai dan hasilnya ditunjukkan pada Gambar 5.

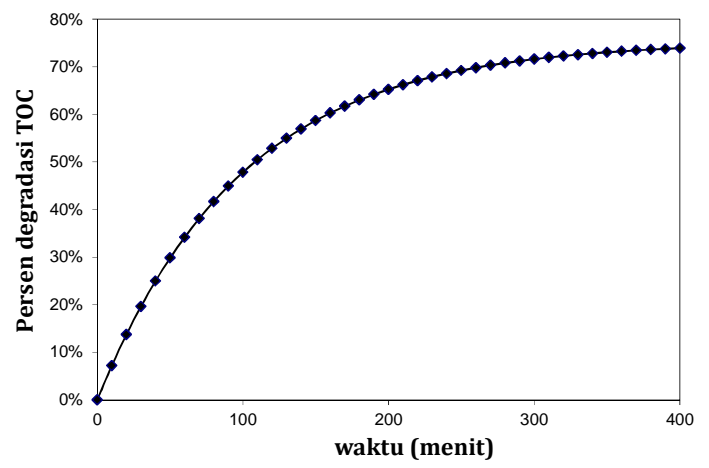

Gambar 5. Persentase degradasi bahan organik dalam sebuah fotoreaktor kontinyu dengan sebelum mencapai kondisi tunak 
Profil konsentrasi bahan organik total dalam reaktor terhadap waktu sebelum mencapai keadaan tunak ditunjukkan pada Gambar 6. Garis putus-putus vertikal pada gambar tersebut menunjukkan waktu yang diperlukan oleh reaktor kontinyu untuk mencapai 99\% nilai konsentrasi tunak TOC adalah 605 menit. Hasil ini sesuai dengan perhitungan waktu untuk mencapai kondisi tunak seperti tertulis pada Persamaan 10. Dengan demikian, reaksi foto fenton dalam reaktor kontinyu berpengaduk dapat dikategorikan sebagai reaksi cepat.

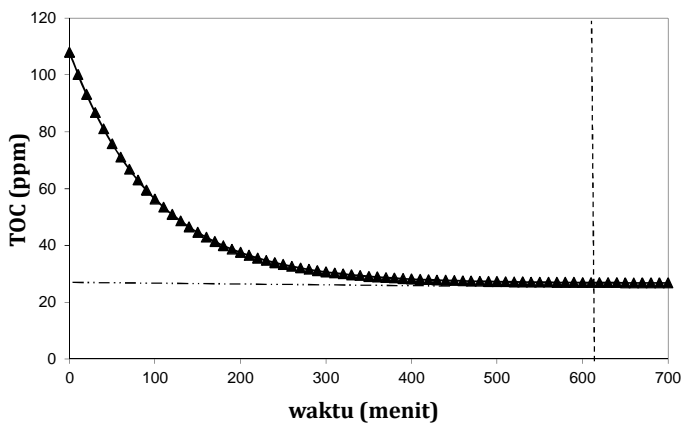

Gambar 6. Hubungan konsentrasi bahan organik (TOC) di dalam fotoreaktor kontinyu terhadap waktu, waktu tinggal = 400 menit. Konsentrasi pada keadaan tunak 26,73 ppm dan waktu untuk mencapai keadaan tunak, $t_{s}=605$ menit

\subsection{Fotoreaktor Kontinyu Tunggal Pada Kondisi Tunak}

Pada kondisi tunak, persentase degradasi bahan organik akan meningkat dengan meningkatnya waktu tinggalnya dalam reaktor. Hal ini ditunjukkan pada Gambar 7. Untuk waktu tinggal di bawah 250 menit, peningkatan konversi bahan organik sangat tajam kemudian peningkatan konversi ini berangsur-angsur turun kecepatannya. Untuk konversi $90 \%$ bahan organik, waktu tinggal umpan dalam fotoreaktor sebesar 1100 menit. Artinya, untuk mengolah 10 liter/menit limbah cair, volume fotoreaktor kontinyu tunggal yang dibutuhkan sebesar $11 \mathrm{~m}^{3}$.

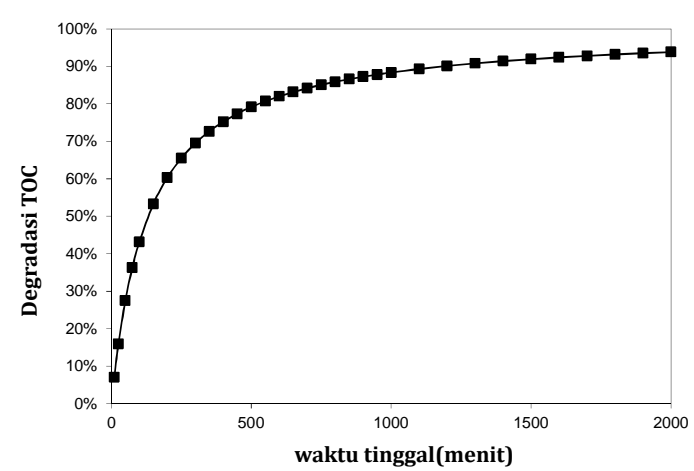

Gambar 7. Degradasi organik dalam reaktor alir kontinyu sebagai fungsi dari waktu tinggal

\subsection{Empat Buah Fotoreaktor Yang Dihubungkan Seri}

Ditinjau dari faktor ekonomi harga alat, diusulkan sistem yang menggunakan 4 fotoreaktor kontinyu yang dihubungkan secara seri. Skema sistem reaktor ini terdapat pada Gambar 2b.

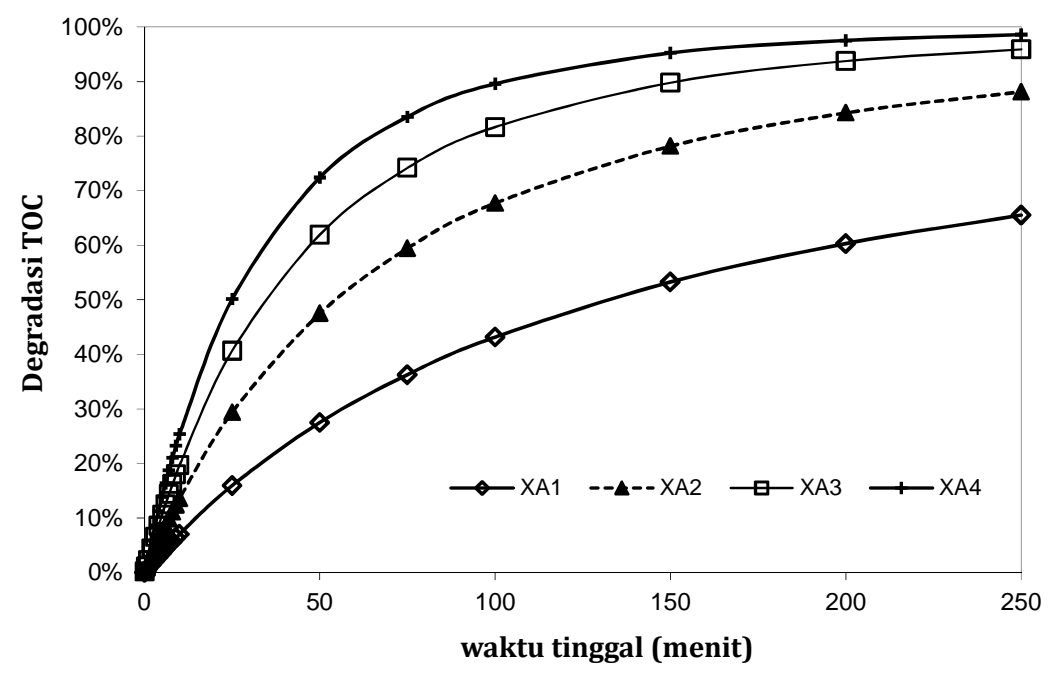

Gambar 8. Degradasi bahan organik pada aliran keluar dari fotoreaktor pertama, kedua, ketiga dan keempat yang dihubungkan secara seri 
Hubungan antara konversi terhadap waktu tinggalnya untuk keempat reaktor tersebut ditunjukkan pada Gambar 8. Jika dirancang menggunakan 4 buah reaktor dengan volume yang sama, waktu tinggal umpan dalam tiap reaktor akan memiliki harga yang sama pula. Untuk merancang empat buah fotoreaktor seri dengan konversi total bahan organik 90\%, diperoleh hasil waktu tinggal untuk masingmasing reaktor sebesar $\tau=100$ menit. Artinya, untuk mengolah 10 liter/menit limbah volume total fotoreaktor yang dibutuhkan sebesar $4 \mathrm{~m}^{3}$. Volume total empat buah reaktor akan 2,75 kali lebih kecil dibandingkan volume sebuah reaktor besar untuk konversi dan laju umpan yang sama.

\section{Kesimpulan}

Dari hasil pengamatan secara batch dan simulasi sistem kontinyu pada reaktor alir berpengaduk dapat disimpulkan bahwa kinetika proses penghilangan warna dalam limbah kopi dapat dinyatakan sebagai reaksi orde satu semu terhadap kandungan bahan organik total (TOC) dalam limbah. Berdasarkan waktu yang diperlukan untuk mencapai keadaan tunak dalam reaktor kontinyu, proses penghilangan warna dalam limbah kopi merupakan reaksi cepat. Apabila digunakan empat buah reaktor alir kontinyu berpengaduk yang dihubungkan secara seri, konversi yang dihasilkan adalah 90\% dengan waktu tinggal tiap reaktor $=100$ menit. Namun, dibutuhkan waktu tinggal reaktor berpengaduk tunggal sebesar 1100 menit untuk mencapai konversi yang sama.

\begin{tabular}{|c|c|}
\hline \multicolumn{2}{|l|}{ Notasi } \\
\hline Abs & $=$ Absorbansi \\
\hline$-r$ & $\begin{aligned}= & \text { laju reaksi degradasi bahan } \\
& \text { organic }\end{aligned}$ \\
\hline $\mathrm{k}$ & $\begin{aligned}= & \text { konstanta kecepatan reaksi orde } \\
& \text { dua }\end{aligned}$ \\
\hline $\mathrm{k}_{\exp }$ & $\begin{array}{l}=\text { konstanta kecepatan reaksi orde } \\
\text { satu semu }\end{array}$ \\
\hline$t_{s}$ & $\begin{aligned}= & \text { waktu untuk mencapai keadaan } \\
& \text { tunak (menit) }\end{aligned}$ \\
\hline TOC & $=$ total organic carbon $(\mathrm{mg} / \mathrm{L})$ \\
\hline$\tau$ & $=$ waktu tinggal (menit) \\
\hline
\end{tabular}

\section{Daftar Pustaka}

Chanakya, H. N.; De Alwis, A. A. P.; Environmental issue and management in primary coffee processing, Process Safety and Environmental Protection, 2004, 82(4), 291300.

Chandra, R.; Bharagava, R. N.; Rai, V., Melaniodins as major colourant in sugarcane molasses based distillery effluent and its degradation, Bioresource Technology, 2008, 99(11), 4648-4660.

Haddis, A.; Devi, R., Effect of effluent generated from coffee processing plant on the water bodies and human health in its vicinity, Journal of Hazardous Materials, 2008, 152(1), 259-262.

Fogler, H. S., Elements of Chemical Reaction Engineering, $3^{\text {rd }}$ edition, Prentice Hall International, Inc., New Jersey, 1999, p. 189.

Sukharaharja, A.; Chayadi, S. A.; Christy, Y., Kinetika Penghilangan Warna dari Limbah Kopi dengan Reaksi Photo-Fenton, Laporan Penelitian Teknik Kimia, Universitas Surabaya, Juli 2010.

Teixeira, A. C. S. C.; Mendes, L.; Stollar, G.; Guardani, R.; Nascimento, C. A. O., Photo-fenton remediation of wastewaters containing agrochemicals, Brazilian Archives of Biology and Technology, 2005, 48, 207-218.

Tokumura, M.; Ohta, A.; Znad, H. T.; Kawase, Y., UV light assisted decolorization of dark brown colored coffee effluent by photo-fenton reaction, Water Research, 2006, 40(20), 3775-3784.

Tokumura, M.; Znad, H. T.; Kawase, Y., Decolorization of dark brown colored coffee effluent by solar photo-Fenton reaction: Effect of solar light dose on decolorization kinetics, Water Research, 2008, 42(18), 4665-4673.

Zhang, H.; Choi, H. J.; Huang, C. P., Treatment of landfill leachate by Fenton's reagent in a continuous stirred tank reactor, Journal of Hazardous Material, 2006, 136(3), 618-623. 